\title{
Relationship Quality Of Health Services With The Level Of Satisfaction Of Hospital Patients
}

\author{
Nuraeni ${ }^{1}$, Azsrul AB2, Haerani ${ }^{3}$ \\ S1 Nursing Study Program, Stikes Panrita Husada Bulukumba, Indonesia ${ }^{1}$ \\ Departemen Community and Family Nursing , Stikes Panrita Husada Bulukumba, Indonesia ${ }^{2}$ \\ Departemen Maternal and Child Healt Nursing, Stikes Panrita Husada Bulukumba ,Indonesia ${ }^{3}$
}

Corresponding Autor : $\underline{\text { Aszrulrul@gmail.com }}$

\begin{abstract}
Patient satisfaction is a patient's level of feeling that arises as a result of the performance of health services obtained, after the patient compares with what he expected so that patient satisfaction is needed quality service. The purpose of this study is to determine the relationship between the quality of health services and the level of patient satisfaction. This study uses an analytical research design with a cross sectional approach. The sample in this study were 47 respondents. The study was analyzed using chi-square test results of the study showed that the independent variable that is the perception of the quality of health services consisting of five dimensions has a relationship with patient satisfaction is reliability with $p=0.000$, responsiveness with $p=0.000$, guarantee with $p=0.002$, empathy with $p=0,000$ and physical evidence with $p=0,000$. The conclusion of this study is the relationship between the quality of service reliability with patient satisfaction, there is a responsive relationship with patient satisfaction, there is a guarantee relationship with patient satisfaction, there is an empathy relationship with patient satisfaction and there is a relationship of physical evidence with patient satisfaction. The advice is expected to health workers to continue to improve the quality of health services in order to achieve patient satisfaction.
\end{abstract}

Keywords : Service Quality, Patient Satisfaction

\section{INTRODUCTION}

Patient satisfaction is one of the most important things in reviewing the quality of services, especially services provided by an agency to its patients. Where patient satisfaction is the level of one's feelings after comparing the performance of patients to the expectations that patients want when they want to seek treatment (Yulfita, Aini, \& Andari, 2016). The quality of health services is the main focus for the community at this time. Awareness and concern for quality is increasing. Demands for improving the quality of health services are often echoed both from service providers and from the public as service users. The quality of health services compiled by the Institute of Madicine (IOM) states the quality of health services is a step towards improving health services both individuals and populations in accordance with the expected health outcomes and in accordance with the latest professional knowledge (Imran, Bagu, \& Baharuddin , 2017). 


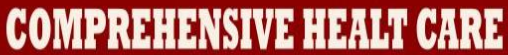

The development of an increasingly critical community, resulting in the quality of services in hospitals in the spotlight both medical services and other forms of service. Patient demands for quality services are not only associated with recovery from illness, but also concerning patient satisfaction with the overall quality of the service process (Rachmawati \& Afridah, 2014). The results of the study of Patient Satisfaction in Class II Inpatient Installation of the Sekayu District General Hospital showed that 65 respondents (44.5\%) stated that the quality of BPJS Health services was not good, and on patient satisfaction as many as 69 respondents (47.3\%) stated that they were not satisfied with BPJS Health services. Seeing this research it can be concluded that there is a relationship between health care and patient satisfaction. If health services are not done well, it will cause dissatisfaction from patients as service users (Nepe, Mudayati, \& Susmini, 2017).

The purpose of this study was to determine whether there is a relationship between the quality of health care and the level of satisfaction of inpatients at H.Andi Sulthan Hospital Dg.Radja Bulukumba in 2018.

\section{MATERIAL AND METHODS}

In this study using analytical research designs with cross sectional approach because they want to know the Relationship between the Quality of Health Services and the Level of Satisfaction of Inpatients at H.Andi Sulthan Hospital Dg.Radja Bulukumba. Population is a generalization area consisting of objects / subjects that have certain qualities and characteristics determined by researchers to be studied and then drawn conclusions (Sugiyono, 2014). The population in this study were patients treated in the inpatient room at H.Andi Sulthan Dg. Radjaumba Hospital as many as 3,835 patients. The sample is part of the number and characteristics possessed by the population. The sampling technique in this study by means of Purposive Sampling is a sampling technique with certain considerations (Sugiyono, 2014).

The instrument used in this study used a questionnaire sheet Data collection used the independent variable and the dependent variable in the form of a questionnaire with a Likert scale approach. Likert scale is used to determine the quality of health services with the level of patient satisfaction. Data were analyzed based on measuring scale and research objectives using computerized program software. Data were analyzed by: (1). Univariate analysis is used to look at proportions. (2). Bivariate Analysis, bivariate test is carried out to find the relationship between the independent variable and the dependent 
variable with the test used is Chi-square when it meets the requirements. The confidence interval taken was $95 \%$ and the accepted significance limit if $\mathrm{p}>0.05$.

\section{RESULTS}

Table1.Distribution of Respondents Characteristics at RSUD H.Andi Sulthan Dg.Radja Bulukumba

\begin{tabular}{lcc}
\hline Characteristics & F & $\%$ \\
\hline Gender & 19 & \\
Male & 28 & 40,4 \\
Girl & 5 & 59,6 \\
Age & 18 & 10.6 \\
Teenager & 24 & 38.3 \\
Adult & & 51,1 \\
Elderly & 30 & \\
Level Of Education & 14 & 63.8 \\
Basic & 3 & 29.8 \\
Intermediate & & 6.4 \\
High & 22 & 46.8 \\
Profession & 13 & 27.7 \\
IRT & 9 & 19.1 \\
Farmers & 3 & 6.4 \\
entrepreneur & & \\
Student & 30 & 63.8 \\
Duration of treatment & 17 & 36.2 \\
3 days & 47 & 100.0 \\
$>3$ days & &
\end{tabular}

Based on (Table 1) shows that of the 47 female respondents more by the number of $28(59.6 \%)$, distribution based on age found that more adults with 18 (38.3\%), then the frequency distribution of respondents based on education was obtained that basic education is more 30 (63.8\%), and the frequency distribution of respondents based on IRT work is more $22(46.8 \%)$, then the distribution of respondents based on length of day of care shows that there is more frequency of length of stay for 3 days with 30 (63.8\%).

Table 2. Frequency Distribution of Respondents Based on Service Quality at H.Andi Sulthan Dg. Radja Bulukumba Hospital

\begin{tabular}{lcc}
\hline Service Quality & $\mathbf{n}$ & Percentage (\%) \\
\hline Reliability & 22 & 46,8 \\
Well & 25 & 53,2 \\
Not good & & \\
Responsiveness & 28 & 59,6 \\
Well & 19 & 40,4 \\
Not good & & \\
Guarantee & 32 & 68,1 \\
Well & 15 & 31,9 \\
Not good & & \\
Empathy & 28 & 59,6 \\
Well & &
\end{tabular}




\section{COMPRABHENSWE HEAH CARE}

\begin{tabular}{lcc}
\hline Not good & 19 & 40,4 \\
Physical Proof & & \\
Well & 25 & 53,2 \\
Not good & 22 & 46,8 \\
\hline Amount & $\mathbf{4 7}$ & $\mathbf{1 0 0 , 0}$ \\
\hline
\end{tabular}

Based on (Table 2) shows the frequency distribution of respondents based on the quality of health services shows that the quality of service based on reliability in the good category 22 (46.8\%), and the category of less 25 (53.2\%), the quality of service based on the responsiveness of the good category 28 (59.6\%), 19 less categories (40.4\%), service quality based on guarantees in good category 32 (68.1\%), category less 15 (31.9\%), service quality based on empathy in good categories 28 (59.6\%), and 19 (40.4\%) less categories, then the quality of service based on good physical evidence categories 25 (53.2\%), 22 less categories (46.8\%).

Table 3. Frequency Distribution of Respondents Based on Patient Satisfaction Level at H.Andi Sulthan Hospital Dg.Radja Bulukumba

\begin{tabular}{lcc}
\hline Patient Satisfaction & n & Percentage (\%) \\
\hline Satisfied & 31 & 66,0 \\
Not satisfied & 16 & 34,0 \\
\hline Amount & $\mathbf{4 7}$ & $\mathbf{1 0 0 . 0}$ \\
\hline
\end{tabular}

Based on (Table 3) shows the frequency distribution of respondents based on the level of patient satisfaction that of 47 respondents the level of satisfaction of patients who were more satisfied 31 (66.0\%), while 16 (34.0\%) respondents were not satisfied.

Table 4. Frequency Distribution of Respondents Based on Quality of Health Services with the level of patient satisfaction

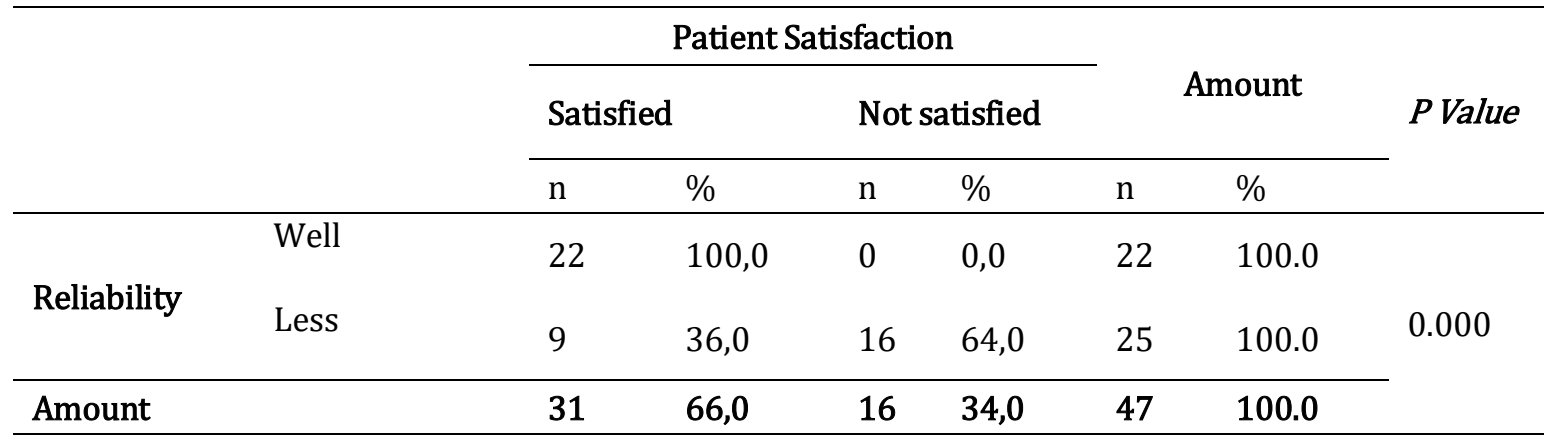

Based on (Table 4) shows the relationship between the quality of health services based on reliability with the level of patient satisfaction shows that the quality of service based on the reliability of the good category in the level of satisfaction is $22(100.0 \%)$, dissatisfied $0(0.0 \%)$, and the category is less in the satisfaction level of $9(36.0 \%), 16$ (64.0\%) dissatisfied. This shows the relationship between the quality of health services based on reliability and the level of patient satisfaction. Chisquare Linear Association test 


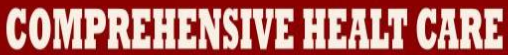

results obtained $\mathrm{p}=0.00(\mathrm{p}<0.05)$, then it was concluded that there is a relationship between the quality of health services based on reliability with the level of patient satisfaction.

The relationship between the quality of health services based on responsiveness with the level of patient satisfaction shows that the quality of service based on responsiveness is good in the satisfaction level of 26 (92.9\%), dissatisfaction 2 (7.1\%), and the category lacks in the level of satisfaction satisfaction amounted to 5 (26.3\%), not satisfied 14 (73.7\%). This shows the relationship between the quality of health services based on responsiveness with the level of patient satisfaction. Chisquare Linear Association test results obtained $p=0.00(p<0.05)$, then concluded that there is a relationship between the quality of health services based on responsiveness with the level of patient satisfaction.

The relationship between the quality of health services based on collateral with the level of patient satisfaction shows that the quality of service based on collateral is good in the satisfaction level of $26(81.2 \%)$, dissatisfied $6(18.8 \%)$ and the less category in the level of satisfaction satisfaction is 5 ( $33.3 \%)$ not satisfied 10 (66.7\%). This shows the relationship between the quality of health services based on guarantees with the level of patient satisfaction. Chisquare Linear Association test results obtained $\mathrm{p}=0.02(\mathrm{p}$ $<0.05)$, then concluded that there is a relationship between the quality of health services based on guarantee with the level of patient satisfaction.

The relationship between the quality of health services based on empathy and the level of patient satisfaction shows that the quality of service based on empathy in both the satisfaction level of 25 (89.3\%), dissatisfaction $3(10.7 \%)$ and the less category in the level of satisfaction satisfaction of 6 (31.6\%) were not satisfied 13 (68.4\%). This shows the relationship between the quality of health services based on empathy with the level of patient satisfaction. Chisquare Linear Association test results obtained $\mathrm{p}=0.00(\mathrm{p}$ $<0.05)$, then it was concluded that there is a relationship between the quality of health services based on empathy with the level of patient satisfaction.

The relationship between the quality of health services based on physical evidence and the level of patient satisfaction shows that the quality of services based on physical evidence either in the level of satisfaction is 24 (96.0\%) dissatisfied 1 (4.0\%) and less in the satisfaction level is 7 (31.8\%) not satisfied 15 (68.2\%). This shows the relationship between the quality of health services based on physical evidence with the level of patient 


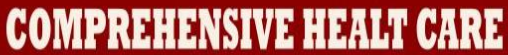

satisfaction. Chisquare Linear Association test results obtained $p=0.00(p<0.05)$, it was concluded that there is a relationship between the quality of health services based on physical evidence with the level of patient satisfaction.

\section{DISCUSSION}

In this study it was seen that there was a significant relationship between the quality of health services based on reliability with the level of patient satisfaction, the quality of health services based on responsiveness with the level of patient satisfaction, the quality of health services based on guarantees with the level of patient satisfaction, the quality of health services based on empathy with the level of patient satisfaction, and the quality of health services based on physical evidence with the level of patient satisfaction at H.Andi Sulthan Dg.Radja Bulukumba Hospital.

From the results of the Chi-square Linear Association Test obtained p =0,000 ( $p$ $<0.05)$, it was concluded that there is a relationship between the quality of health services based on reliability with the level of patient satisfaction. This is in line with the results of the study of Sri Yuniarti, et al (2015) found that there is a correlation between the quality of service reliability with the level of patient satisfaction with a value of $p=0.004$. (Yuniarti, Parjo, \& Irsan, 2015). From the results of the Chi-square Linear Association Test, the value of $p=0,000(p<0.05)$ concluded that there is a relationship between the quality of health services based on responsiveness with the level of patient satisfaction. This is in line with the results of the research by Djeinne Thresye Pangerapan et al (2018). The results show that there is a relationship between the quality of health services based on responsiveness and the level of patient satisfaction with a p value of 0.047 .

From the results of the Chi-square Linear Association Test, the value of $p=0.002(p$ $<0.05)$ concluded that there is a relationship between the quality of health services based on guarantee and the level of patient satisfaction. This is in line with the results of a study conducted by Jusriani et al (2016). The results show that there is a relationship between the quality of health services based on collateral and the level of patient satisfaction with a p value $=0.027$. (Jusriani, Junaid, \& Lisnawaty, 2016).

From the results of the Chi-square Linear Association Test the value of $p=0,000$ ( $p$ $<0.05)$ concluded that there is a relationship between the quality of health services based on empathy and the level of patient satisfaction Djeinne Thresye Pangerapan et al. (2018). patient satisfaction with $\mathrm{p}=0.020$. 


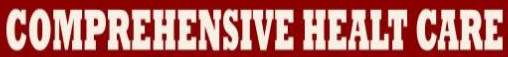

From the results of the Chi-square Linear Association Test, the value of $p=0,000$ ( $p$ $<0.05)$ concluded that there is a relationship between the quality of health services based on physical evidence and the level of patient satisfaction Djeinne Thresye Pangerapan et al. (2018). with the level of patient satisfaction with a value of $p=0.001$.

\section{CONCLUSIONS}

Based on the research results above, it was concluded that there was a significant relationship between the quality of health services based on reliability, responsiveness, assurance, empathy, and physical evidence with the level of patient satisfaction at H.Andi Sulthan Hospital Dg.Radja Bulukumba in 2018. The results of this study hopefully can increase student knowledge at STIKES Panrita Husada Bulukumba and for Hospitals to maintain the quality of health services in order to continue to improve the quality of services provided and conduct regular and continuous patient satisfaction surveys to evaluate the performance of health services and the quality of inpatient services at H.Andi Sulthan Hospital Dg.Radja Bulukumba

\section{REFERENCES}

Yulfita, Aini, \& Andari, E. (2016). Analisis Kualitas Pelayanan Terhadap Kepuasan Pasien Berobat di Puskesmas Pembantu Desa Pasir Utama. Jurnal IImiah .

Imran, A., Bagu, A. A., \& Baharuddin, Y. (2017). Mutu Pelayanan Kesehatan Terhadap Kepuasan Pasien Di Pusat Kesehatan Angkatan Darat Kabupaten Takalar. p-ISSN:24433861

Rachmawati, I., \& Afridah, W. (2014). Mutu Pelayanan Gizi dengan Tingkat Kepuasan Pasien. Jurnal ilmiah kesehatan

Nepe, L., Mudayati, S., \& Susmini. (2017). Hubungan Pelayanan Kesehatan dengan Kepuasan Pasien peserta BPJS Di Rumah Sakit Umum Daerah Kefenamu Kabupaten Timur Tengah Utara. Nursing News .

Sugiyono. (2014). Statistika untuk Penelitian. Bandung: ALFABETA,CV. 


\section{COMPRAHENSWEHABH CARE}

Pangerapan, D. T., Palandeng, O. E., \& M.Rattu, A. J. (2018). Hubungan Antara Mutu Pelayanan Dengan Kepuasan Pasien Di Poli Klinik Penyakit Dalam Rumah Sakit Umum GMIM Pancaran Kasih Manado. jurnal kedokteran klinik.

Jusriani, Junaid, \& Lisnawaty. (2016). Hubungan mutu pelayanan kesehatan dengan kepuasan pasien rawat jalan puskesmas puriala kecamatan puriala kabupaten konawe.

Yuniarti, S., Parjo, \& Irsan, A. (2015). Hubungan Antara Kualitas Pelayanan Rumah Sakit Dengan Tingkat Kepuasan Pasien BPJS di Ruang Perawatan RSUD Sultan Syarif Mohamad Alkadrie Pasien BPJS di Ruang Perawatan RSUD Sultan Syarif Mohamad Alkadrie Pasien BPJS di Ruang Perawatan RSUD Sultan Syarif . 36 (2004-2014). 